ZALEWSKA J. 1999. The genus Najas (Najadaceae) in Poland: remarks on taxonomy, ecology, distribution
and conservation - Fragmenta Floristica et Geobotanica 44(2): 401-422.
ZARZYCKI K. \& SZELAG Z. 2006. Red list of the vascular plants in Poland. - W: Z. MirEK, K. ZARZYCKI,
W. WoJewODA \& Z. SZELAG (red.), Red list of plants and fungi in Poland, s. 11-20. W. Szafer Institute
of Botany, Polish Academy of Sciences, Kraków.

Sabina Klich i Alina Stachurska-Swakoń, Instytut Botaniki Uniwersytetu Jagiellońskiego, ul. Gronostajowa 3,30-387 Kraków,Polska; e-mail: sabina.klich@doctoral.uj.edu.pl

Wptynęto: 28.02.2020 r.; przyjęto do druku: 15.09.2020 r.

DOI: https://doi.org/10.35535/ffgp-2020-0056

\title{
Allium ursinum i A. scorodoprasum (Amaryllidaceae) - rzadkie gatunki w zabytkowym parku podworskim w Kamieńcu (Wielkopolska)
}

Parki podworskie lub inne elementy stałe w krajobrazie antropogenicznym (np. cmentarze, grodziska, kurhany) są niejednokrotnie miejscem o interesującej florze (CELKA 2011; NowIŃSKA 2016). Szczególnie cenne ze względów botanicznych okazują się miejsca opuszczone lub takie, gdzie zaniechano prac pielęgnacyjnych. Wówczas w takich warunkach dawne gatunki uprawne dziczeją i w przypadku ich dalszego spontanicznego rozwoju mogą uzyskać miano trwałego elementu lokalnej flory (CZARNA 2001).

Park w Kamieńcu (gm. Kamieniec, powiat Grodzisk Wlkp., woj. wielkopolskie; $\left.52^{\circ} 10^{\prime} 04,23^{\prime \prime} \mathrm{N}, 16^{\circ} 27^{\prime} 49,51^{\prime \prime} \mathrm{E}\right)$ jest przydworskim założeniem ogrodowym utrzymanym w nurcie krajobrazowym (naturalistycznym), pochodzącym z końca XIX w., wpisanym do rejestru zabytków województwa (nr rej. 1983/A z 10.12.1984 r.). Park jest jednym z wielu przykładów, gdzie od wielu lat nie prowadzi się żadnych prac utrzymaniowych zieleni. Dzięki koncepcji założenia parkowego w stylu angielskim miejsce to wyewoluowało w siedlisko przyrodnicze o interesującym aspekcie florystycznym. Wykonana inwentaryzacja dendroflory w 2019 r. w parku w Kamieńcu (MAĆKOWIAK 2019) stała się przesłanką niniejszej pracy. W jej wyniku na terenie parku (o powierzchni 4,32 ha) odnaleziono rzadkie w skali regionu i kraju gatunki Allium ursinum oraz A. scorodoprasum (kwadrat ATPOL o boku 2,5 km: BD2856; ZAJĄC 1978).

Allium scorodoprasum L. (czosnek wężowy), jest gatunkiem europejsko umiarkowanopontyjsko-pannońskim o centrum występowania w zasięgu pannońskim (ZAJAc \& ZAJĄC 2009), tj. głównie region Rumunii, Ukrainy, Chorwacji, Węgier, byłej Jugosławii, Bułgarii. Ponadto gatunek o rozporoszonym występowaniu na terenie Polski, Niemiec, Szwecji oraz Wielkiej Brytanii (MEusEL \& JÄGER 1992).

Allium scorodoprasum jest gatunkiem rzadkim w kraju, najczęściej spotykanym w Wielkopolsce, na Kujawach i Pomorzu Gdańskim, ale również na pogórzach (ZAJĄC \& ZAJĄC 2019). Dawna roślina uprawna o statusie archeofita we florze polskiej (ZARZYCKI i in. 2002), wymieniona w „czerwonej liście” (KAŹMIERCZAKOwA i in. 2016), jak i „czerwonej księdze” (KAŹMIERCZAKOWA i in. 2014), jako gatunek narażony na wymarcie (VU). Populacja gatunku 
w parku w Kamieńcu jest rozproszona na całym areale, przy czym najliczniej występuje w części południowej parku, głównie pod okapem Robinia pseudoacacia, Acer psedoplatanum oraz A. platanoides. Zacienienie stanowiska jest znaczne $\mathrm{z}$ uwagi na duże zwarcie krzewów i wynosi ok. 65-70\%. W runie głównie towarzyszą gatunki nitrofilne, tj.: Aegopodium podagraria, Alliaria petiolata, Chelidonium majus i Urtica dioica. Nie odnotowano szczególnych zagrożeń antropogenicznych oddziałujących na populację czosnku wężowego.

Allium ursinum L. (czosnek niedźwiedzi), gatunek podelementu europejskiego umiarkowanego (ZAJĄC \& ZAJĄC 2009). Swoim zasięgiem obejmuje znaczny teren centralnej i zachodniej Europy, występując głównie w obszarach górskich oraz podgórskich (MeusEL \& JÄGER 1992). Większość krajowych stanowisk położonych jest w jego naturalnym górskim zasięgu.

Czosnek niedźwiedzi jest gatunkiem objętym ochroną częściową (ROZPORZĄDZENIE 2014), występującym na południu kraju w wilgotnych lasach liściastych, grądach, buczynach, nad potokami, przy źródliskach. W pozostałej części kraju jest notowany rzadko (ZAJĄC \& ZAJĄC 2019), był umieszczony w poprzednim wydaniu polskiej „czerwonej listy" (ZARZYCKI \& SZELAăG 2006) jako gatunek narażony na wyginięcie poza głównym obszarem występowania (kategoria V). W obrębie gatunku wyróżniono dwa podgatunki subsp. typicum oraz subsp. ucrainicum, przedstawiając ich charakterystyczne cechy, np. brodawkowanie epidermy szypuły (RoLA 2012). Ponadto autorka przedstawiła rozdział geograficzny tychże podgatunków, co pozwala stwierdzić, że populacja czosnku niedźwiedziego w parku w Kamieńcu to podgatunek typowy.

Na podstawie prowadzonych od wielu lat obserwacji własnych stwierdzono, że zasięg tego gatunku utrzymuje się na podobnej powierzchni i zajmuje ok. 0,30 ha. Występuje na skłonie grodziska pierścieniowego (z pomnikowymi dębami szypułkowymi) oraz poniżej jego, w siedlisku łęgowego lasu dębowo-wiązowo-jesionowego (Ryc. 1). Szacowana wielkość populacji to ok. 200-300 tys. osobników. Zacienie utrzymuje się na poziomie 50-60\%. W runie na zwartym stanowisku czosnku niedźwiedziego odnotowano: Aegopodium podagraria, Alliaria petiolata, Ficaria verna, Gagea lutea, G. minima, Galium aparine, Phyteuma spicatum, Stellaria nemorum, Veronica hederifolia i Urtica dioica.

Opisane stanowisko czosnku niedźwiedziego jest drugim znanym w Wielkopolsce (na podstawie ZAJĄC \& ZAJĄC 2019). Ogólnie zagrożeniem dla gatunku jest jego zbiór jako surowca zielarskiego, który możliwy jest wyłącznie na obszarze województw: śląskiego, małopolskiego i podkarpackiego, po uzyskaniu właściwej derogacji na podstawie przepisów ustawy o ochronie przyrody (Ustawa 2020). W przypadku omawianej populacji Allium ursinum, poza pozyskaniem tego gatunku, zagrożeniem jest nadmierne wydeptywanie.

Warto ograniczyć aktualny negatywny wpływ człowieka na populacje obu gatunków poprzez realizację stosownych działań ochronnych. Skutecznym i podstawowym narzędziem może być edukacja ekologiczna lokalnej społeczności. Przykładowo wiązać się to może z wykonaniem ścieżki edukacyjnej wraz z montażem kilku tablic informacyjnych o różnorodności biologicznej w parku, w tym o występowaniu rzadkich gatunków roślin.

Populacje obu gatunków czosnków w parku w Kamieńcu są cennymi w zasięgu regionalnym. Ich stanowiska wymagałyby wprowadzenia odpowiedniej formy ochrony przyrody na tym terenie, np. użytku ekologicznego. 


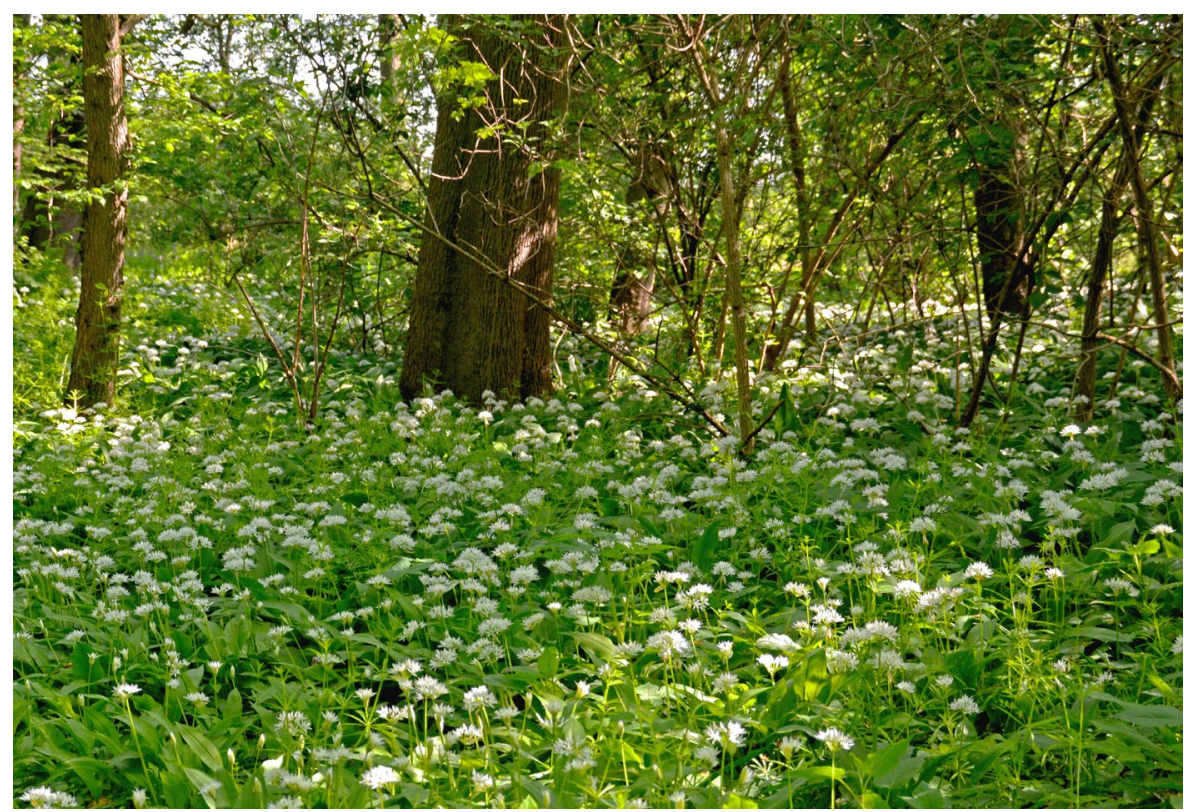

Ryc. 1. Kwitnący Allium ursinum - aspekt wiosenny w parku w Kamieńcu

Fig 1. Blooming Allium ursinum - spring aspect in the park in Kamieniec

Summary. Allium ursinum and A. scorodoprasum (Amaryllidaceae) - a rare garlic species in a historic landscape park in Kamieniec (Wielkopolska). In 2019, a new locality of two rare Allium species was found in a park in Kamieniec during an inventory of dendroflora. Populations of Allium ursinum and A. scorodoprasum are unique in the Wielkopolska region. The area where it occurs is an old park designed in the English landscape style of garden. The park ought to be protected as a conservation area of unique character.

\section{LITERATURA}

CELKA Z. 2011. Relics of cultivation in the vascular flora of medieval West Slavic settlements and castles. - Biodiversity: Research and Conservation 22: 1-110.

CZARnA A. 2001. Flora naczyniowa cmentarzy ewangelickich w Koźminie i Koźmińcu (Nizina Wielkopolska). - Roczniki Akademii Rolniczej w Poznaniu CCCXXXIV, Botanika 4: 27-37.

Kaźmierczakowa R., Zarzycki K. \& Mirek Z. (red.). 2014. Polska czerwona księga roślin. Paprotniki i rośliny naczyniowe. Wyd. 3. s. 895. Instytut Ochrony Przyrody, Polska Akademia Nauk, Kraków.

Kaźmierczakowa R., Bloch-OrŁowska J., Celka Z., Cwener A., Dajdok Z., Michalska-Hejduk D., PAwlikowski P., SzCZĘ́́NIAK E. \& ZiARneK K. 2016. Polska czerwona lista paprotników i roślin kwiatowych. s. 44. Instytut Ochrony Przyrody Polskiej Akademii Nauk, Kraków.

MaĆKOWIAK Ł. 2019. Inwentaryzacja dendroflory zabytkowego parku w Kamieńcu. s. 56. Mskr. Urząd Gminy Kamieniec, Poznań.

Meusel H. \& JÄGER J. 1992. Vergleichende Chorologie der zentraleuropäischen Flora. 3. s. 333. Gustav Fisher Verlag, Jena.

Nowińska R., Czarna A., CzeKalski M. \& Morozowska M. 2016. Vascular flora of selected palace parks in the Wielkopolska region. - Steciana 20(3): 137-157. 
Rola K. 2012. Taxonomy and distribution of Allium ursinum (Liliaceae) in Poland and adjacent countries. - Biologia 67(6): 1080-1087.

RozPORZĄDZENIE Ministra Środowiska z dnia 9 października 2014 r. w sprawie ochrony gatunkowej roślin (Dz. U. 2014 r., poz. 1409).

Ustawa z dnia 16 kwietnia 2004 r. o ochronie przyrody (Dz. U. 2020 r., poz. 55).

ZAJĄC A. 1978. Założenia metodyczne „Atlasu rozmieszczenia roślin naczyniowych w Polsce”. - Wiadomości Botaniczne 22(3): 145-155.

ZAJĄC A. \& ZAJĄC M. (red.). 2019. Atlas rozmieszczenia roślin naczyniowych w Polsce - dodatek. s. 306. Instytut Botaniki Uniwersytetu Jagiellońskiego, Kraków.

ZAJĄC M. \& ZAJĄC A. 2009. Elementy geograficzne rodzimej flory Polski. s. 94. Nakładem Pracowni Chorologii Komputerowej Instytutu Botaniki Uniwersytetu Jagiellońskiego, Kraków.

ZARZYCKI K. \& SZELĄG Z. 2006. Czerwona lista roślin naczyniowych w Polsce. - W: Z. MiReK, K. ZARZYCKI, W. Wojewoda \& Z. Szeląg (red.). Czerwona lista roślin i grzybów Polski, s. 11-20. Instytut Botaniki im. W. Szafera, Polska Akademia Nauk, Kraków.

Zarzycki K., Trzcińska-Tacik H., Różański W., Szeląg Z., WoŁek J. \& Korzeniak U. 2002. Ekologiczne liczby wskaźnikowe roślin naczyniowych Polski. s. 183. Instytut Botaniki im. W. Szafera, Polska Akademia Nauk, Kraków.

ŁukASz MaćKowiak, Kowalewo 6, 64-061 Kamieniec, Polska; e-mail: lukaszmackowiak123@ gmail.com

Wptynęto: 24.05.2020 r.; przyjęto do druku: 17.12.2020 r.

DOI: https://doi.org/10.35535/ffgp-2020-0057

\section{Nowe stanowiska Luronium natans (Alismataceae) w Polsce}

Luronium natans (L.) Raf. (elisma wodna) jest europejskim endemitem obejmującym zasięgiem północno-zachodnią, zachodnią oraz środkowowschodnią część kontynentu. Liczne stanowiska są rozmieszczone na Wyspach Brytyjskich oraz w Europie Środkowej (SzMEJA 2014). Sporadycznie gatunek jest notowany na Półwyspie Skandynawskim oraz w Danii (LANSDOWn 2013).

W Polsce Luronium natans występuje głównie na obszarze Pojezierzy Wschodniopomorskiego, Południowopomorskiego i Zachodniopomorskiego oraz na Pobrzeżu Koszalińskim i Szczecińskim. Ponadto, gatunek stwierdzono w rejonie Nysy Łużyckiej na stanowisku Potok (RosAdZIŃSKI 2014). Populacja pomorska występuje w jeziorach oligotroficznych i mezotroficznych, od miękkowodnych do umiarkowanie zasobnych w wapń. Elisma wodna rośnie w nich na głębokości od 0 do 2,0 m, najczęściej w płatach zbiorowisk roślinnych z klasy Littorelletea uniflorae Br.-Bl. et R.Tx. 1943 oraz w zbiorowiskach wodnych mszaków: Sphagnum denticulatum Brid. i Warnstorfia exannulata (Schimp.) Loeske (CHMARA i in. 2015). Luronium natans tworzy też własne zbiorowisko: Luronietum natantis Szańkowski ex Šumberová, Čtvrtlíková et Bauer (Šumberová i in. 2011). 